\title{
Study of Bhakra reservoir operation
}

\author{
P S RAO* and S RAMASESHAN $\dagger$ \\ * Indian Institute of Management, Bannerghatta Road, Bangalore 560076, India \\ † Civil Engineering Department, Indian Institute of Technology, Kanpur 208016, India.
}

\begin{abstract}
The study outlines the methodology for working out a multiobjective reservoir operation with conjunctive utilization of surface and groundwater. Irrigation and power have been considered the two objectives for operation of the reservoir. The results of this study are compared with those achieved with conventional operation in the past and show that there is an increase in irrigation by 7 to $8 \%$ due to conjunctive use of surface and groundwater. The trade-off between irrigation and power has been developed and discussed. The transformation surface between three objectives viz., power, irrigation and carry-over storage has been developed and the merits of carry-over storage have been discussed.
\end{abstract}

Keywords. Reservoir operation; multiobjective analysis; conjunctive use of water.

\section{Introduction}

Irrigation and power are two of the most important purposes for which surface and groundwater resources are used. The integrated operation of a complex system is necessary for efficient management of limited resources to meet irrigation and power demands. The importance of the conjunctive utilization of surface and groundwater in an integrated framework has been realised (Irrigation Commission 1972) but has not been put into practice perhaps due to institutional constraints and lack of coordination. However, using a systems analysis procedure it seems possible to study the integrated operation of a multiobjective reservoir system with conjunctive utilization of surface and groundwater. A case study of the Bhakra reservoir, which has been in operation since 1966 is described in this paper. The object of this study is to analyse the past operation of the reservoir within a multiobjective framework to evaluate the trade-offs between irrigation and power demands in the past. The study also demonstrates the methodology and procedures in multiobjective analysis within an integrated framework.

\section{System description}

\subsection{The Bhakra}

The Bhakra system in Punjab constitutes one of India's biggest projects (figure 1). The Bhakra dam is a $225.55 \mathrm{~m}$ high concrete gravity dam built on the river Sutlej. The river, the largest tributary of the river Indus, begins in Tibet and enters the Indo-Gangetic plains near Bhakra. The total catchment area upstream of Bhakra is $56,980 \mathrm{~km}^{2}$. The rainfall in the catchment varies over the basin with an annual average of around $875 \mathrm{~mm}$. Govindsagar, the reservoir formed by the Bhakra dam, has a gross capacity of 


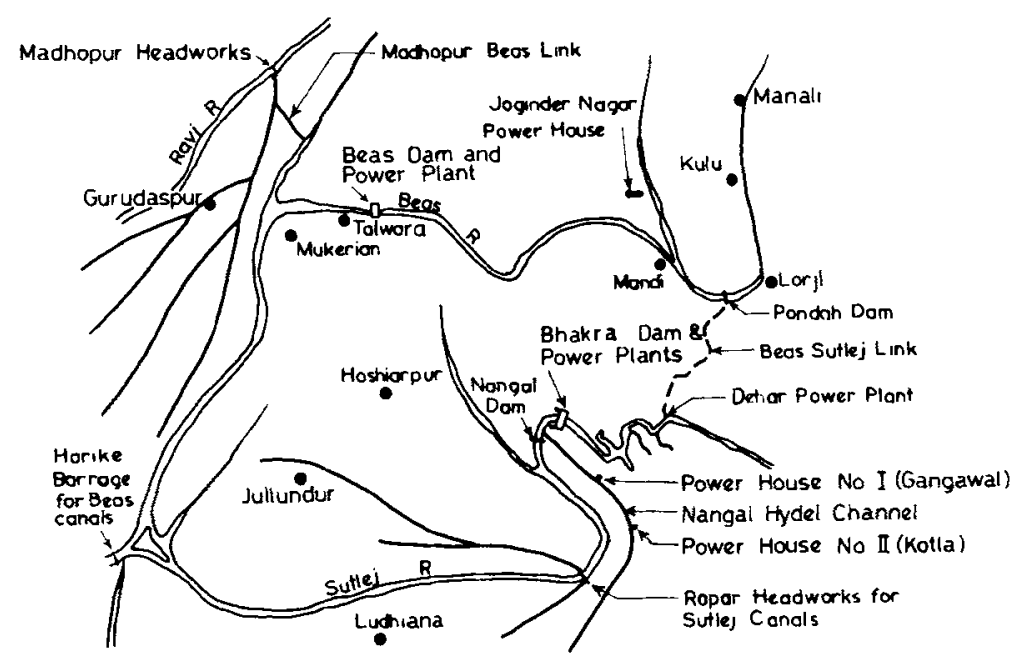

Figure 1. Interconnected system of the rivers Ravi, Beas and Sutlej.

$9876 \mathrm{~m}$ cu $\mathrm{m}$ and a live storage capacity of $7814 \mathrm{~m}$ cu $\mathrm{m}$ above a dead storage level of $445.62 \mathrm{~m}$. It covers an area of $168.35 \mathrm{~km}^{2}$ when full. The total run-off at Bhakra for a dependable year works out to $13,723 \mathrm{~m} \mathrm{cu} \mathrm{m}$ and that for a mean year to $16,441 \mathrm{~m} \mathrm{cu} \mathrm{m}$. A dependable year has been adopted by the planners as a hypothetical year in which the mean discharge of any 10-day period is equalled or exceeded by the corresponding 10day mean discharges in $67 \%$ of the years for which data are considered.

The river flows are high for the four months from June to September due to snowmelt and monsoon rains. Almost $47 \%$ of the river flow of a dependable year occurs during these four months. Water from Govindsagar (Bhakra reservoir) can be passed through the turbines of two power houses, one on the right bank and the other on the left bank at the foot of the Bhakra dam. Both the power houses have 5 turbines each. Each of the generators in the right-bank power house has a maximum capacity of $120 \mathrm{MW}$ when the head is $116 \mathrm{~m}$ or more, whereas each of the left-bank generators has a maximum capacity of $90 \mathrm{MW}$ when the head is $110 \mathrm{~m}$ or more. These capacities fall respectively to $70 \mathrm{MW}$ and $53 \mathrm{MW}$ when the head falls to about $80 \mathrm{~m}$. Thus the powergenerating capacity varies from a maximum of $1050 \mathrm{Mw}$ to a minimum of $615 \mathrm{MW}$.

About $11 \mathrm{~km}$ downstream of the Bhakra dam is the Nangal reservoir formed by the $28.95 \mathrm{~m}$ high Nangal dam. It serves as a head regulator for control of irrigation releases. Part of the water from Nangal is released to the Nangal hydel channel which is $64.48 \mathrm{~km}$ long and has a carrying capacity of 353.75 cu mecs. The remaining water is released to the Sutlej. The Nangal hydel channel supplies water to two power houses in its path at Ganguwal and Kotla with a total installed capacity of $154 \mathrm{Mw}$. Water from the Nangal hydel channel is then divided between the Bhakra main canal and the Sirhind canal. The Bhakra main canal serves some of the canals of the old western Jamuna canal system which were merged with the Bhakra system and so receives some supplies from the western Jamuna canal.

Downstream of Nangal, there are headworks at two places on the river Sutlej at Ropar and Harike. At Ropar, water is diverted to the Bist Doab and Sirhind canals. The Beas river joins the Sutlej at Harike. Water is diverted at Harike to the Rajasthan feeder 
and the Ferozepur feeder for the Eastern and Bikaner canals and the Sirhind feeder. Water from all these canals is distributed through the network of the branch canals of the irrigation distribution system. The details of the system are given in figure 1.

Punjab possesses large resources of groundwater which are generally suitable for irrigation. Due to the presence of alluvium, a large-scale programme to install tubewells has been undertaken. The State in 1974 had about 126,000 tubewells and another 75,000 were proposed under the fifth plan (1973-1978). An area of 0.6 to $0.8 \mathrm{~m}$ ha suffers from waterlogging. The installation of tubewells would also solve the waterlogging problem to some extent.

\subsection{Irrigation demands}

Bhakra was primarily designed to improve irrigation over an area of $1.42 \mathrm{mha}$ and irrigate an additional 2.43 million hectares. The area served consists of parts of Punjab, Haryana and Rajasthan. The main crops grown in this region are bajra, cotton, maize, rice, jowar, sugarcane, oilseeds, pulses and fodder during the monsoon (kharif) season; and wheat, gram, oilseeds, barley, potatoes and fodder during the winter (rabi) season. Irrigation requirements given in table 1 were assessed when the project was planned

Table 1. Irrigation requirements of the Bhakra system

\begin{tabular}{|c|c|c|c|c|}
\hline Month & Period & $\begin{array}{l}\text { No. } \\
\text { of } \\
\text { days }\end{array}$ & $\begin{array}{c}\text { Daily } \\
\text { irrigation } \\
\text { requirements } \\
\text { (in cumec days) }\end{array}$ & $\begin{array}{l}\text { Total irrigation } \\
\text { requirements } \\
\text { (in cumec days) }\end{array}$ \\
\hline & \multicolumn{4}{|c|}{ Filling period (from 1st of June to 20th of September) } \\
\hline June & $1-30$ & 30 & $715 \cdot 71$ & 21471 \\
\hline July & $1-31$ & 31 & $561 \cdot 13$ & 17395 \\
\hline August & $1-31$ & 31 & $561 \cdot 13$ & 17395 \\
\hline \multirow[t]{3}{*}{ September } & $1-20$ & 20 & $711 \cdot 63$ & 14233 \\
\hline & & & & 70494 or $6100 \mathrm{~m} \mathrm{cu} \mathrm{m}$ \\
\hline & \multicolumn{4}{|c|}{ Depletion period (from 21st September to 31st of May) } \\
\hline September & $21-30$ & 10 & 711.63 & 7116 \\
\hline \multirow[t]{2}{*}{ October } & $1-15$ & 15 & $727 \cdot 71$ & 10916 \\
\hline & $16-31$ & 16 & $654 \cdot 63$ & 10474 \\
\hline November & $1-30$ & 30 & $654 \cdot 64$ & 19639 \\
\hline \multirow[t]{3}{*}{ December } & $1-10$ & 10 & $611 \cdot 76$ & 6118 \\
\hline & $11-15$ & 5 & $363 \cdot 67$ & 1818 \\
\hline & $16-31$ & 16 & $345 \cdot 80$ & 5533 \\
\hline \multirow[t]{2}{*}{ January } & $1-15$ & 15 & $345 \cdot 80$ & 5187 \\
\hline & $16-31$ & 16 & $363 \cdot 67$ & 5819 \\
\hline \multirow[t]{2}{*}{ February } & $1-10$ & 10 & $390 \cdot 46$ & 3905 \\
\hline & $11-28$ & 18 & $545 \cdot 52$ & 9819 \\
\hline March & $1-31$ & 31 & $545 \cdot 52$ & 16911 \\
\hline \multirow[t]{2}{*}{ April } & $1-15$ & 15 & $345 \cdot 80$ & 5187 \\
\hline & $16-30$ & 15 & $418 \cdot 89$ & 6283 \\
\hline \multirow[t]{2}{*}{ May } & $1-31$ & 31 & $703 \cdot 50$ & 21809 \\
\hline & & & & 136534 or $11800 \mathrm{mcum}$ \\
\hline Total 6100 & $=17900$ & & & \\
\hline
\end{tabular}


and were modified only slightly since, although the irrigation demands have changed due to the introduction of high-yielding varieties of crops which require more water. The need to reassess irrigation requirements and revise the demands has been well recognised.

Irrigation requirements are high from September to November owing to the water required for the maturing of the kharif crops and the preparation and sowing of the rabi crops. The requirements are low from December to April, except in the latter half of February and in March when water is required for the maturing of the rabi crops. The rabi crop requirements are smaller than the kharif crop requirements. In May and June, the requirements are again high due to the preparation and sowing of the kharif crops. During the monsoon season also the requirements are quite high as the areas where such water is to be utilized have low rainfall.

\subsection{Power demands}

The releases from the reservoir were originally planned mainly for irrigation. Only 987 m cum (revised upwards to $1360 \mathrm{~m}$ cu m recently) was earmarked for releases for power generation. These releases were in addition to those made for irrigation. It was assessed that the releases for power made would yield a firm power of $282 \mathrm{MW}$ from the Bhakra power houses during an empirically-defined dry year.

\subsection{Current operating policy}

Each year the Bhakra Management Board (BMB) conducts operational planning studies, referred to as water power studies, of the system as part of the planning to regulate the supplies from the Bhakra reservoir. The water year from 1 June to 31 May is divided into two periods. June 1 to 20 September is the 'filling period' when supplies are generally available due to snowmelt and the monsoons and the reservoir fills up. September 21 to 31 May is the 'depletion period' when water is released from reservoir storage to meet the demands of irrigation and power.

During the filling period, irrigation demands are met in full subject to the constraint that the reservoir is not allowed to deplete. This means that demands are not fully met if they exceed inflows. This could happen because of the delayed arrival of monsoon, during breaks in monsoon and also in relatively dry years.

Water power studies are conducted for the depletion period using the available utilizable stored volume of water in the reservoir and dependable year or dry year inflows for the depletion period. Although on the basis of 10-day inflows any particular inflow figure of a river in a dependable year would have a probable availability of $67 \%$, the total yearly inflow of a river at any particular site, corresponding to the dependable year has a probable availability of about $85 \%$. A dry year is taken as the driest year on record. It is not possible to meet the full irrigation requirements of the depletion period every year. The ratio of deliveries to demands is called the reservoir factor (RF) defined as

$$
\begin{aligned}
R F= & (\text { Total storage available in reservoir }+ \text { expected inflow during de- } \\
& \text { pletion period } \pm \text { gains or losses upto the point of offtake of } \\
& \text { canals. }) /(\text { Total canal requirements during the depletion period.) }
\end{aligned}
$$

The water power studies of BMB indicate that the firm power level is not a constant throughout the depletion period. The firm power level is $15-30 \%$ higher from 21 
September to 10 December than from 10 December to 31 May. These studies include the possibility of carryover storage from a good year to the subsequent year. Based on water power studies a decision is taken on 21 September regarding regulation of supplies from the reservoir during the depletion period. The decision implies choice of (i) RF (ii) firm power level, and (iii) minimum reservoir drawndown level to be reached on 31 May (this determines the carryover storage, if any).

\section{Review of earlier studies}

The Bhakra system has been studied and reported by economists (Raj 1960; Ansari 1968; Minhas et al 1972; Reidinger 1974) and by engineers (Singh 1964; Mehndiratta \& Hoon 1973). Raj concerned himself with some economic aspects of the Bhakra Nangal project and a preliminary analysis of selected investment criteria. Ansari studied the economics of irrigation rates and examined the basic arguments for incurring financial deficits on irrigation supplies. Reidinger studied the institutional rationing of canal water in an area in Hissar district which is served by one of the Bhakra canals.

Minhas et al (1972) made extensive simulation studies of the operations of the Bhakra system (i) to determine for the depletion period the efficient combinations of firm power with certainty and irrigation supplied with a given confidence level, (ii) to evaluate the increase in availability of both irrigation and firm power due to conjunctive utilization of surface and groundwater and to compare the economics of this scheme with that of a thermal back-up. They observed that "in the absence of a satisfactory economic measure of the relative worth of irrigation and power, one cannot determine an ideal operating policy". But the important question of devising such a satisfactory economic measure has been left unanswered in the study. As such the trade-off possibilities delineated in a probabilistic sense cannot be used by decision-makers in choosing the point of operation of the reservoir at the end of the filling period.

Singh (1964) put forward the idea of using seasonally available secondary power for lifting groundwater by tubewells in the general framework of conjunctive utilization of surface and ground waters. Minhas et al (1972) noted that the tubewells, when operated solely to augment irrigation supplies, can utilize power which would otherwise go waste and which therefore is 'free' in the economic sense of the term (since the economic value of goods is based on their alternative uses). Operated solely to increase the level of firm power output, tubewells can convert useless secondary power to valuable firm power. Singh also pointed out the role of groundwater development as an antiwaterlogging measure.

Mehndiratta \& Hoon (1973) report the methodology adopted by вMB to regulate supplies from the Bhakra reservoir from 1966 to 1972 . This report greatly helped in understanding the system and serves as the source material for the present study. Water power studies of BMB, given in tables 2 and 3, reveal that according to the planning studies for the operation of the reservoir in 1969-70 and 1970-71, considerable secondary or dump power was generated during the early part of the depletion period.

From the studies reviewed, it is clear that (i) the sudden peak in the irrigation demands during the rabi sowing season, which is the early part of the depletion period of the reservoir, necessitates the release of water with high potential for power generation for irrigation; (ii) consumers of power who get used to the higher level of firm power supplied during this period find it difficult to reduce their consumption of 


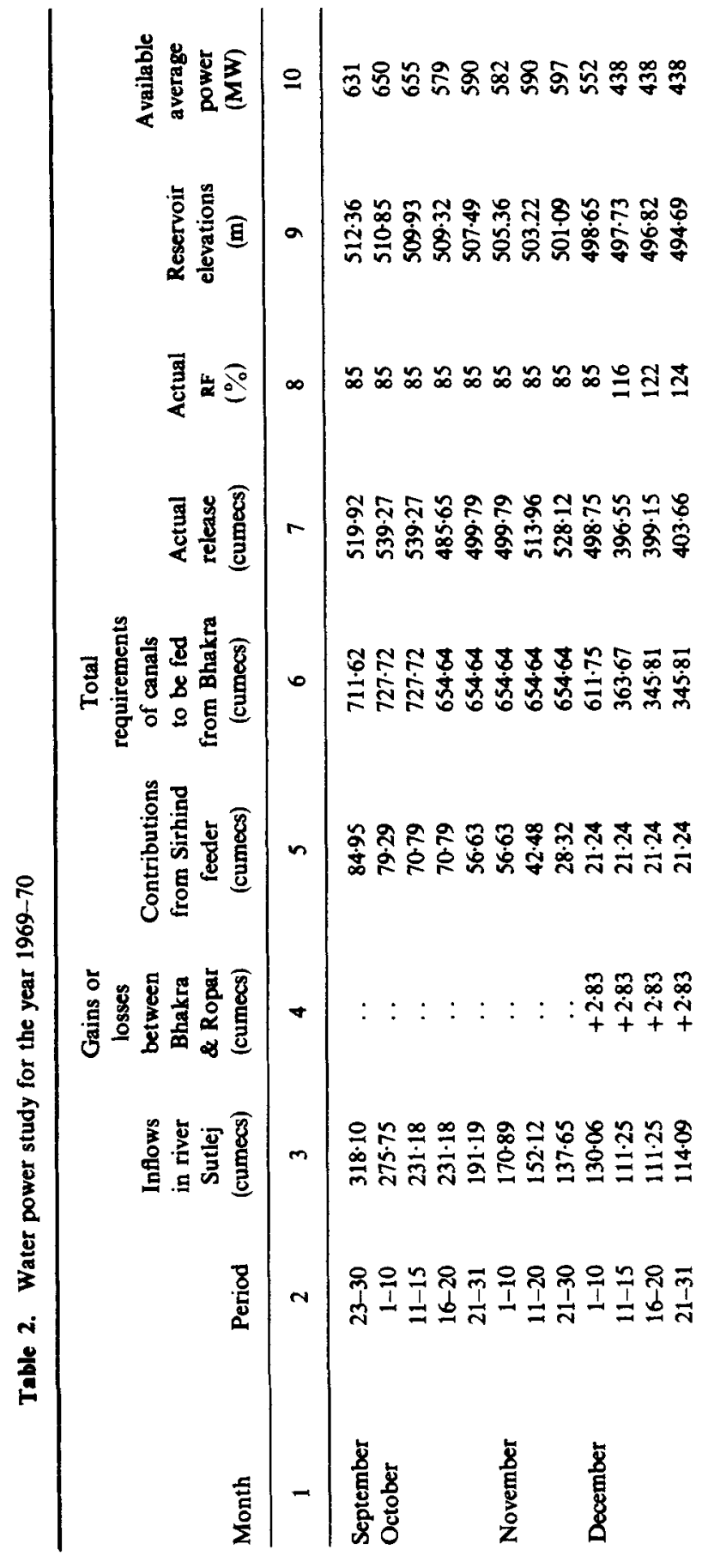




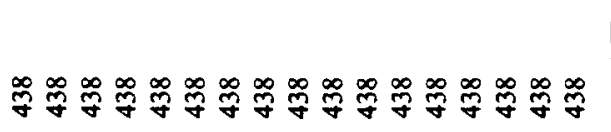

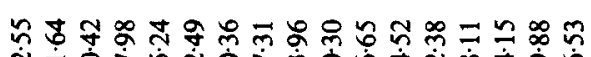

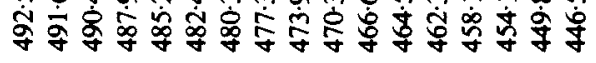

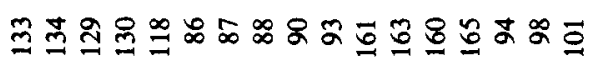

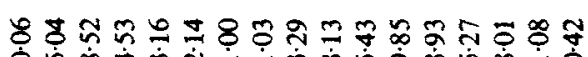

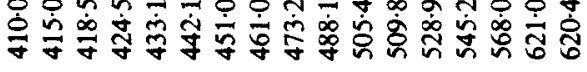

क

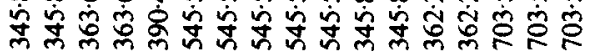

我 $\infty$ 央 خें寸

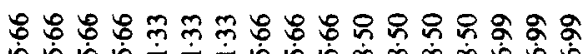

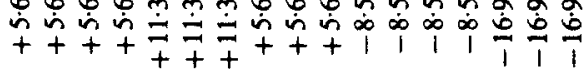

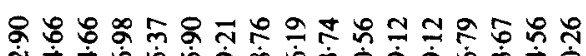

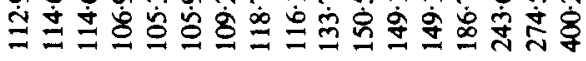

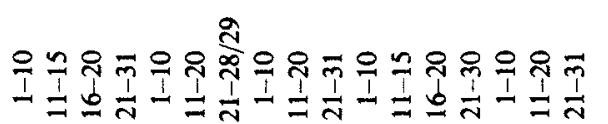

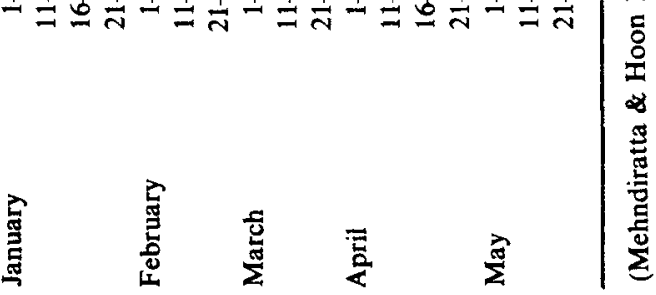




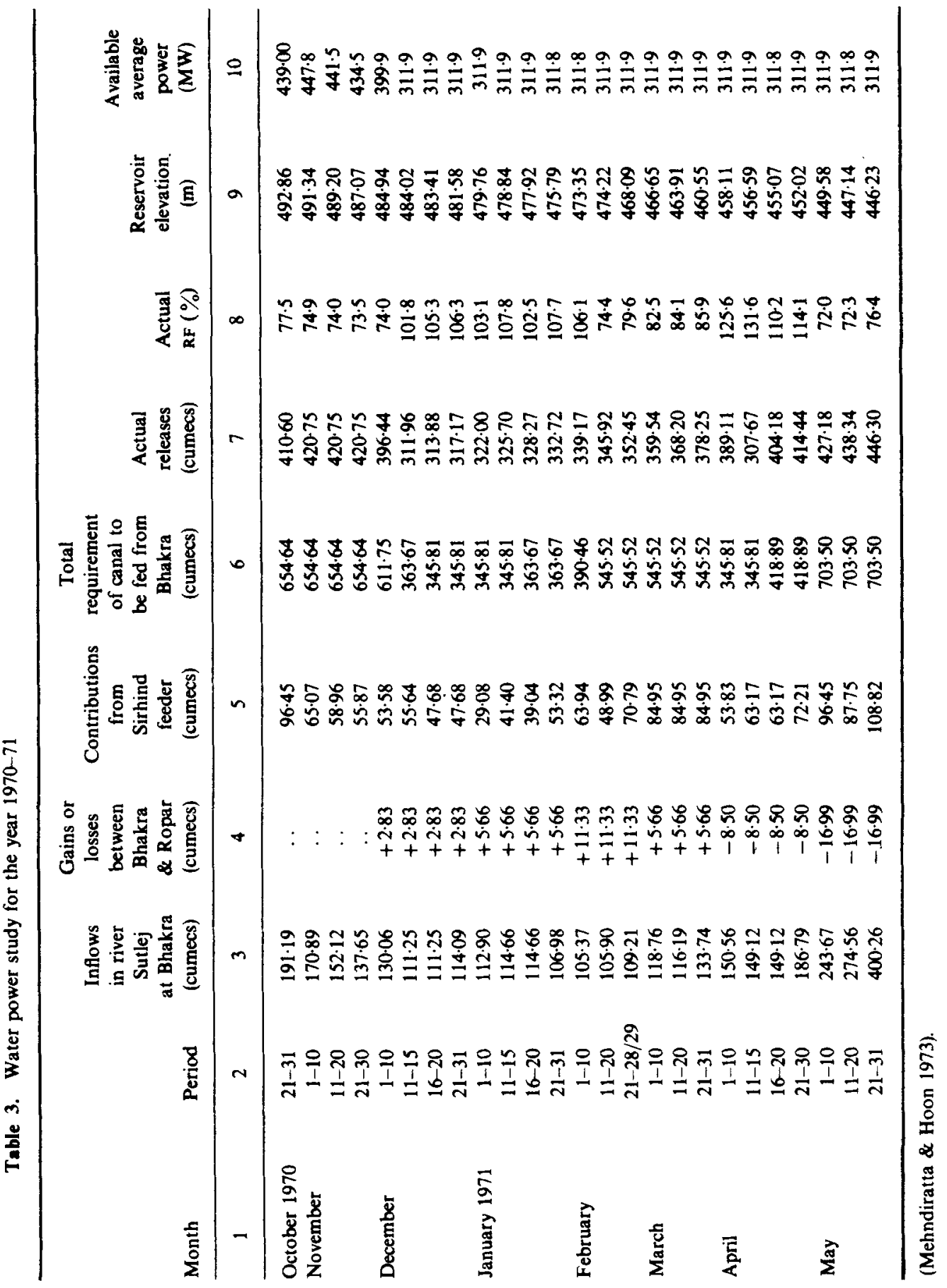


power subsequently; (iii) it has not been possible for BMB to satisfactorily coordinate the releases for irrigation and power; and (iv) conjunctive utilization of surface and groundwaters may lead to increased firm power level and reliability of irrigation.

\section{Conjunctive utilization}

\subsection{Conjunctive-use concept}

The Bhakra surface water system has been described in $\$ 2.1$. There has also been intensive development of groundwater by the public and private sectors. Such combined use of surface and groundwaters as is now practised was not preplanned but has come into being out of necessity. Though the concept of conjunctive utilization of surface and groundwaters has been put forward and widely advocated, it has not been applied systematically. The Irrigation Commission (1972) recognized this fact and recommended that schemes for conjunctive use of surface and groundwaters in existing irrigation schemes should be accorded high priority and that a systematic study should be made by each State to identify areas where conjunctive use is feasible. It appears that conjunctive utilization is considered as the planned development of surface and ground waters for irrigation. It has not been sufficiently realised, despite the good work of Singh (1964) and Minhas et al (1972) that conjunctive utilization enables the operating authorities to cope with the differences in time distribution of irrigation and power demands in an optimal way and that it is a means of converting secondary power to valuable firm power. The model described below and applied to the water power studies of BMB for 1969-70 and 1970-71 seeks to emphasize the conjunctive utilization concept and demonstrate the benefits of its application.

\subsection{Conjunctive-use model}

A linear programming model which is an adaptation of a model proposed by Thomas $\&$ Revelle (1966) for the Aswan High dam on the Nile river has been developed. Figure 2 is a schematic representation of the model.

The objective is to minimize the discharge from the reservoir during the period 23 September to 30 November. The model is based on the fact that if secondary or dump power generated could be used to lift groundwater and supply part of the irrigation demand, then it is possible to reduce the discharges from the reservoir during this period.

$$
\text { Objective function: Minimize } \sum_{i=1}^{N} x_{i} \text {, }
$$

where $i=$ index for the subperiod $i$; subscript $i$ denotes the value of the variable in subperiod $i, N=$ number of subperiods, and $X=$ release from the reservoir in cumec days.

\subsection{Constraints}

4.3a Power constraint: The reservoir release in each subperiod should generate the firm power supplied in that subperiod.

$$
X_{i} \geqslant P_{i} / K_{i} \quad(\text { for all } i) \text {, }
$$




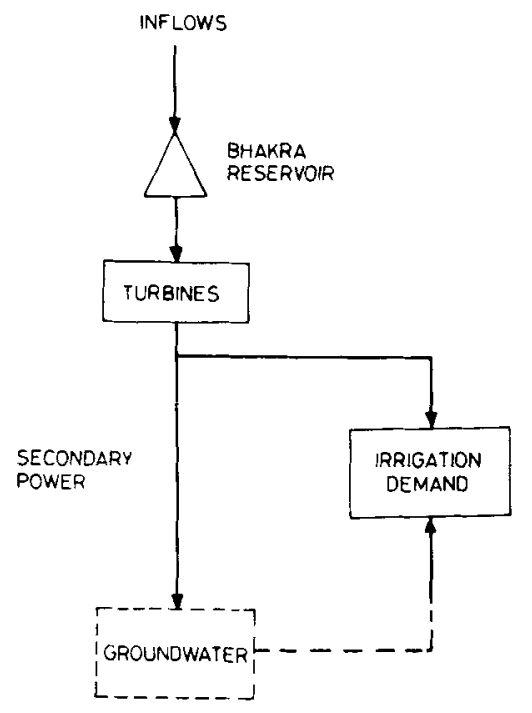

Figure 2. Conjunctive use model for the Bhakra reservoir.

where $P=$ firm power demand, and $K=$ power conversion factor (energy rate function) i.e., power generated by unit volume of water in $\mathrm{mw}$ per cumec.

4.3b Irrigation constraint: The irrigation demand will be met from two sources: (i) releases from the reservoir and (ii) groundwater lifted by the excess, if any, of power generated over firm power level. The amount of dump power generated should be sufficient to lift the groundwater component of the irrigation demand. This is the modification introduced in the model of Thomas \& Revelle (1966) to adapt it to the present problem. Whereas surplus surface water is stored in the aquifers for later use in their model, surplus power is used to lift existing groundwater in this model,

$$
X_{i} \geqslant A_{i}-m_{i}\left(K_{i} X_{i}-P_{i}\right)
$$

where $A=$ irrigation demand, and $m=$ volume of groundwater lifted by unit power (cumecs/Mw). When the irrigation demand is overwhelming, this constraint is binding and hence holds as an equality.

4.3c Continuity constraint: The continuity constraint specifies that releases upto any time cannot exceed the sum of storage and inflows upto that time. As the reservoir is nearly full during the early depletion period considered in this problem this constraint will not be binding.

$$
\sum_{i=1}^{s} X_{i} \leqslant V+\sum_{i=1}^{s} I_{i} \text { for all } s \text { with } s=1,2, \ldots, N,
$$

where $V=$ reservoir storage volume at the beginning of the depletion period, and $I=$ inflow into the reservoir.

\subsection{Data and assumptions}

The model is used to study the regulation of the Bhakra reservoir during the depletion period for 1969-70 and 1970-71. Data from the water power studies of BMB (tables 2 and 3) are used in the study. 
Turbine efficiencies of the order of 0.85 and pump efficiencies of 0.7 are common. The product of the turbine and pump efficiencies is assumed to be 0.6 . Tail race elevation $(357 \mathrm{~m})$ is taken from Singh (1965). The power conversion factors $K_{i}$ are computed from the data in tables 2 and 3. They are assumed constant during the subperiods. As the length of the subperiod is short ( 8 to 10 days), the variation in the reservoir elevation is small and the head is high, the effect of this approximation is negligible.

The depth to groundwater is assumed to be $15 \mathrm{~m}$ in October and $17 \mathrm{~m}$ in November. Minhas et al (1972) mentioned that in Haryana and Punjab groundwater level rises to 15 to $25 \mathrm{~m}$ ( 50 to $80 \mathrm{ft}$ ) below ground surface even for deep tubewells. In many areas groundwater is available much nearer the surface at depths of 3 to $4 \mathrm{~m}$ especially after the rainy season in October and November. The assumption of 15 to $17 \mathrm{~m}$ depth to groundwater is conservative.

The firm power level and reservoir factor adopted by вмв for the early depletion period up to November 30 are respectively $552 \mathrm{MW}$ and 0.85 in 1969-70 and $400 \mathrm{MW}$ and 0.75 in $1970-71$. These values are used in this study.

\subsection{Discussion of results}

The model is applied to study the regulation of the Bhakra reservoir for $1969-70$ and 1970-71 during the early depletion period when irrigation alone is constraining. The results given in tables 4 and 5 show that the power used for lifting groundwater is much smaller than the secondary power generated according to BMB studies and that the actual releases of water from the reservoir are reduced by conjunctive use. For example, it is seen from table 4 that during 11-15 October the secondary power generated is $103 \mathrm{Mw}$ whereas the model suggests $9.9 \mathrm{Mw}$ of power for lifting the groundwater component of the irrigation demand resulting in a saving of 364.35 cumec days of water in the reservoir. It is found that 2800 cumec days (i.e. $243 \mathrm{~m} \mathrm{cu} \mathrm{m}$ ) of water could be saved in the reservoir during the period 23 September to 30 November (table 4). This is $7.87 \%$ of the total releases made during the same period (table 2). A similar value of $7 \cdot 28 \%$ is computed for $1970-71$ from table 5 .

The water so conserved in the reservoir can be used either to expand the irrigated area and help enhance food production under the rabi crop or alternatively it can subsequently help reduce the depletion rate of the reservoir when power demand is constraining and it has a twofold effect. The conserved water increases the storage in the reservoir and also increases the head available for power generation. At the end of the depletion period, the reservoir could end up at a higher elevation. Although $7-8 \%$ of saving of water appears small, it corresponds to $243 \mathrm{~m}$ cu $\mathrm{m}$ of water and is higher in volume than the evaporation loss of $155.63 \mathrm{mcum}$ from Bhakra reservoir during 1969-70. Since irrigation is generally not constraining during the remainder of the depletion period a 7 to $8 \%$ increase in irrigation supply during this period can increase the total output of irrigation by a corresponding percentage and this is significant.

\section{Multiobjective analysis}

\subsection{The concept}

Multiple purposes should be treated as multiple objectives when there is conflict between them as the nature of their consequences is noncommensurable and the linkages between the purposes and the objectives they set out to serve are not known. 

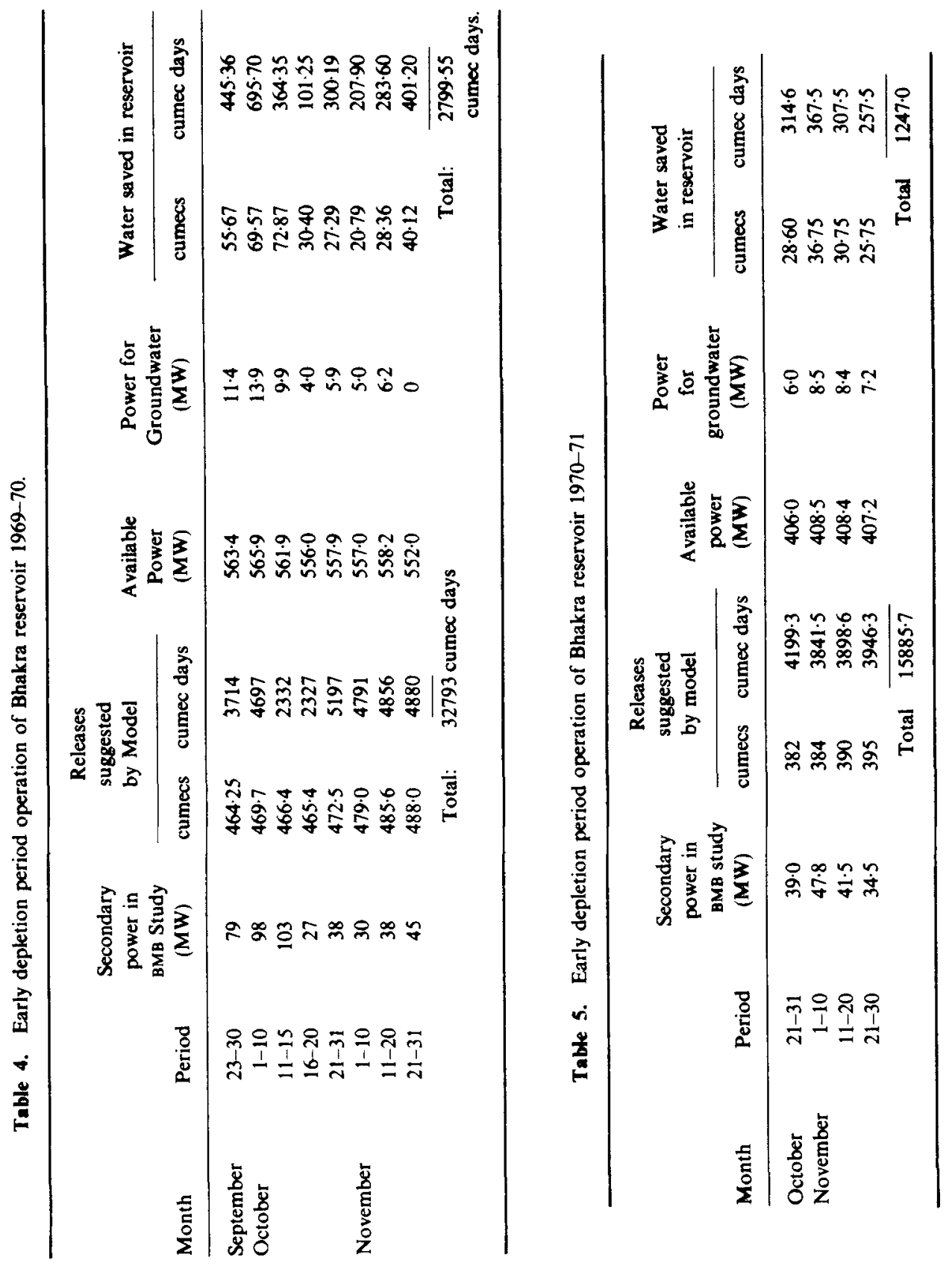
There has been sharp competition for and conflict in the use of the Bhakra reservoir storage for irrigation and power (Mehndiratta \& Hoon 1973; Reidinger 1974). In the planning stage Bhakra was considered more of an irrigation project and the power benefits were secondary. A firm power of $282 \mathrm{MW}$ was expected from Bhakra power houses in a dry year. With the rapid increase in power load in the region, the position has completely changed. The power demand overrides other interests of the project during most of the months and it has not been possible to satisfactorily coordinate the releases. It is therefore worthwhile to consider irrigation and power as the two objectives to operate the Bhakra system and to study the complementarity and conflict between the two for the six years for which data are available.

\subsection{The model}

Thomas \& Revelle (1966) used a linear programming (LP) model and for a given storage in Aswan High dam derived the transformation curve between irrigation and power by maximizing power for different levels of irrigation demands. A similar approach is used to study the planned and actual depletion period operation of the Bhakra reservoir. The LP model is as follows:

Objective function: maximize $P$,

where $P=$ firm power level in $\mathrm{Mw}$.

\subsection{Constraints}

5.3a Irrigation constraint: The reservoir release in each subperiod should meet the irrigation requirements to be supplied from the reservoir,

$$
X_{i} \geqslant A_{i} \text {, with } i=1,2, \ldots, N,
$$

where $N=$ number of subperiods during the depletion phase of the reservoir, $X=$ reservoir release in cumec days, and $A=$ irrigation requirements to be supplied from the reservoir in cumec days.

5.3b Power constraint: The reservoir release should generate the committed firm power in each subperiod.

$$
X_{i} \geqslant \frac{P \cdot \beta_{i} n_{i}}{K_{i}} \text { with } i=1,2, \ldots, N
$$

where $\beta_{i}=$ firm power coefficient in subperiod $i, n_{i}=$ number of days in subperiod $i$, and $K=$ power conversion factor(Mw/cu mec).

5.3c Continuity constraint: The total volume of water released from the reservoir during the depletion period should not exceed the total utilizable storage in the reservoir at the beginning of the depletion period and the inflows in the depletion period.

$$
\sum_{i=1}^{N} X_{i} \leqslant V+\sum_{i=1}^{N} I_{i}
$$

where $V=$ volume of reservoir storage utilized during depletion period in cumec days, and $I=$ river inflow into the reservoir. 

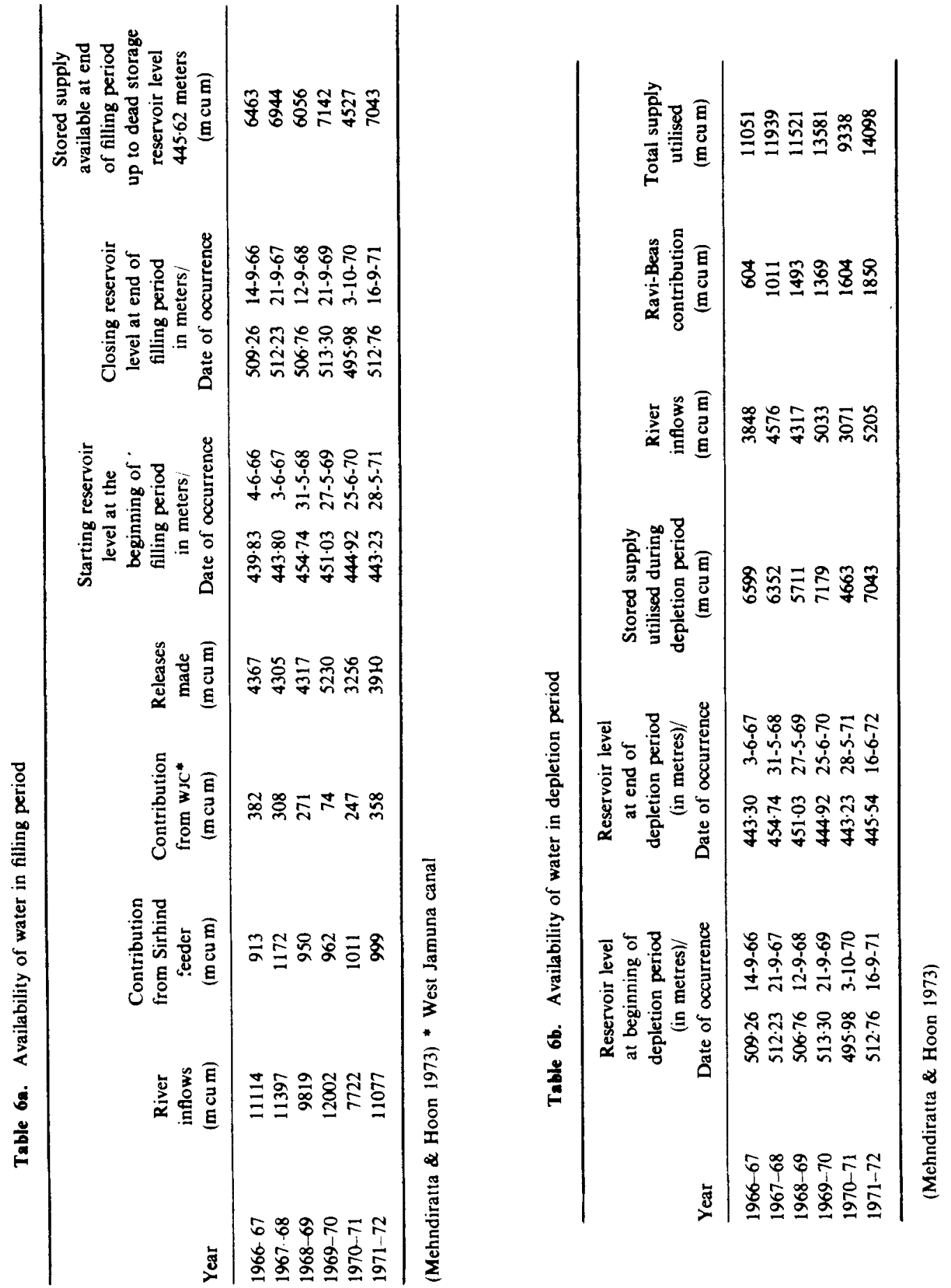


\subsection{Data and assumptions}

5.4a Number of subperiods: The water and power studies о вмв generally divides the depletion period from 23 September to 31 May into 29 periods (table 2). An LP package on the time-sharing computer terminal at the Harvard University Centre for Population Studies limits the total number of constraints to 50 . To facilitate its use, the depletion period is divided into 24 subperiods by aggregating some of the subperiods in the waterpower studies.

$5.4 \mathrm{~b}$ Irrigation requirements: The irrigation requirements in cumecs are given in table 1. During the depletion period, the irrigation requirements may be satisfied only partly as defined by the reservoir factor $(\mathrm{RF})$. They are computed for values of $\mathrm{RF}$ ranging from 0.6 to 1 at increments of 0.05 .

The expected inflow during depletion period has two components: (i) the inflow into the reservoir and (ii) the inflows of the Ravi and Beas rivers that contribute through the Sirhind feeder and supply part of the irrigation requirements of the Bhakra command. The Sirhind feeder (Ravi-Beas) contributions vary from year to year and the data are shown in table 6 . While the break-up of these contributions period-wise is available for 1969-70 and 1970-71 from tables 2 and 3, an assumption is needed for the other four years. The proportion of the total flow in each subperiod for these years is assumed to be the average of such proportions for 1969-70 and 1970-71. Gains or losses upto the point of offtake of canals are available for each of the subperiods from tables 2 and 3.

5.4c Firm power level: The BMB chose for operation the results of water study no. VI for 1969-70 (table 7), study no. 1 for 1970-71 (table 8) and study no. VIII for 1971-72

Table 7. Summary of water power studies for $1969-70$

\begin{tabular}{|c|c|c|c|c|c|}
\hline Study No. & $\begin{array}{l}\text { Starting } \\
\text { reservoir } \\
\text { level in } \\
\text { meters }\end{array}$ & $\begin{array}{l}\text { Pattern of } \\
\text { inflow }\end{array}$ & $\begin{array}{l}\text { Minimum } \\
\text { reservoir } \\
\text { level in } \\
\text { meters }\end{array}$ & $\begin{array}{l}\text { Reservoir } \\
\text { factor } \%\end{array}$ & Power \\
\hline I & $513 \cdot 28$ & Dry year & 445.62 & 75 & $\begin{array}{l}22-9-69 \text { to } 31-12-69550 \mathrm{MW} \\
1-1-70 \text { to } 20-5-70450 \mathrm{MW} \\
21-5-70 \text { to } 31-5-70289 \mathrm{MW}\end{array}$ \\
\hline II & $513 \cdot 28$ & Dry year & $445 \cdot 62$ & 75 & $\begin{array}{l}22-9-69 \text { to } 31-12-69512 \mathrm{MW} \\
1-1-70 \text { to } 31-5-70441 \mathrm{MW}\end{array}$ \\
\hline III & $513 \cdot 28$ & Dry year & $445 \cdot 62$ & 97 & $\begin{array}{l}\text { Minimum power } 282 \mathrm{MW} \\
\text { was ensured and releases } \\
\text { were proposed in the interest } \\
\text { of irrigation }\end{array}$ \\
\hline IV & $513 \cdot 28$ & Dependable year & $445 \cdot 62$ & 78 & $\begin{array}{l}22-9-69 \text { to } 31-12-69500 \mathrm{MW} \\
1-1-70 \text { to } 30-4-70450 \mathrm{MW} \\
1-5-70 \text { to } 31-5-70500 \mathrm{MW}\end{array}$ \\
\hline V & $513 \cdot 28$ & Dependable year & 445.62 & 80 & $\begin{array}{l}22-9-69 \text { to } 10-12-69524 \mathrm{MW} \\
11-12-69 \text { to } 31-5-70450 \mathrm{MW}\end{array}$ \\
\hline VI & $513 \cdot 28$ & Dependable year & $445 \cdot 62$ & 85 & $\begin{array}{l}22-9-69 \text { to } 10-12-69552 \mathrm{MW} \\
11-12-69 \text { to } 31-5-70438 \mathrm{MW}\end{array}$ \\
\hline VII & $513 \cdot 28$ & Dependable year & $445 \cdot 62$ & 100 & $\begin{array}{l}\text { Minimum power of } 282 \mathrm{MW} \\
\text { was ensured and releases } \\
\text { were proposed in the interest } \\
\text { of irrigation }\end{array}$ \\
\hline
\end{tabular}


Table 8. Summary of water power studies for 1970-71

\begin{tabular}{|c|c|c|c|c|c|}
\hline $\begin{array}{l}\text { Study } \\
\text { No. }\end{array}$ & $\begin{array}{l}\text { Starting } \\
\text { reservoir } \\
\text { level in } \\
\text { metres }\end{array}$ & $\begin{array}{l}\text { Pattern } \\
\text { of } \\
\text { inflows }\end{array}$ & $\begin{array}{l}\text { Minimum } \\
\text { reservoir } \\
\text { level in } \\
\text { metres }\end{array}$ & $\begin{array}{l}\text { Reservoir } \\
\text { factor } \%\end{array}$ & Power \\
\hline I & $\begin{array}{l}494.76 \text { on } \\
1 \text { st October }\end{array}$ & $\begin{array}{l}\text { Dependable } \\
\text { year }\end{array}$ & 445.62 & 75 & $\begin{array}{l}\text { Up to 10th Dec. } \\
1970-400 \mathrm{MW} 11 \text { th } \\
\text { December } 1970 \text { to } \\
\text { 31st May } 1971- \\
312 \mathrm{MW}\end{array}$ \\
\hline II & $\begin{array}{l}494.76 \text { on } \\
\text { 31st October }\end{array}$ & Dry year & $445 \cdot 62$ & 75 & $\begin{array}{l}\text { Up to 10th Dec. } \\
1970-400 \mathrm{MW} 11 \text { th } \\
\text { December } 1970 \text { to } \\
31 \mathrm{st} \text { May } 1971- \\
300 \mathrm{MW}\end{array}$ \\
\hline
\end{tabular}

(Mehndiratta \& Hoon 1973)

(table 9). The $\beta_{i}$ values corresponding to the same were used in this study for the respective years. The $\beta_{i}$ were found to be respectively 1.26 in 1969-70 and 1.282 in 1970-71. For 1966 to 1969 for which no data are available, a distribution similar to $1969-70$ and $1970-71$ with a $\beta_{i}$ value of 1.27 is used.

5.4d Power conversion factors: The power conversion factors $K_{i}$ for $1969-70$ and 1970-71 are deduced from the data in tables 2 and 3 respectively and the relationship between $K_{i}$ and reservoir elevation is derived. For the other four years, the approximate reservoir elevations for each of the subperiods are estimated from the anticipated and actual depletion curves in figures 3 (a to $\mathrm{f}$ ) and the power conversion factors corresponding to these elevations are used in this study. These depletion curves generally correspond to RF values in the ranges of 0.75 to 0.85 . For other RF values, the depletion curves would be somewhat different and the reservoir elevations and hence the power conversion factors would also be different. However, for simplicity, it is assumed that the conversion factors are independent of the RF value and the same conversion factors as in the water power studies of вмв are used in each of the subperiods. From the solution thus obtained, it is possible to determine the reservoir elevations implied and hence determine a new set of values of $K_{i}$ and repeat the procedure till convergence is obtained. However, the irrigation requirement is constraining generally only from 23 September to 10 December when the reservoir elevation is very high and the depletion rate is low. Such refinement is not considered here.

5.4e Sutlej river inflows: This study assumes the dependable year inflows for planning as in the case of water power studies of BMB. They are obtained from Mehndiratta \& Hoon (1973) and Lamba \& Prem (1975) for all years except for 1971-72 for which there is a discrepancy between the two reported values. The dependable year inflow for that year is corrected by interpolation. These are shown in table 10. For actual operation, actual river inflows (table 6b) are used. 
Table 9. Summary of water power studies $1971-72$

\begin{tabular}{|c|c|c|c|c|c|}
\hline $\begin{array}{c}\text { Study } \\
\text { No. }\end{array}$ & $\begin{array}{l}\text { Starting } \\
\text { reservoir } \\
\text { level in } \\
\text { metres }\end{array}$ & $\begin{array}{l}\text { Pattern } \\
\text { of } \\
\text { inflows }\end{array}$ & $\begin{array}{l}\text { Minimum } \\
\text { reservoir } \\
\text { level in } \\
\text { metres }\end{array}$ & $\begin{array}{l}\text { Reservoir } \\
\text { factor } \\
\text { up to } \\
\text { 10th Dec. } 71\end{array}$ & Power \\
\hline I & 512.06 & Dependable year & $445 \cdot 92$ & $85 \%$ & $\begin{array}{l}512 \mathrm{MW} \text { up to } 10 \text { th } \\
\text { December } 1971 \text { and } \\
444 \mathrm{MW} \text { thereafter } \\
\text { up to } 31-5-72\end{array}$ \\
\hline II & $512 \cdot 06$ & Dependable year & $451 \cdot 41$ & $85 \%$ & $\begin{array}{l}512 \mathrm{MW} \text { up to } 10-12- \\
71 \text { and } 430 \mathrm{MW} \text { from } \\
11-12-71 \text { to } 31-5-72\end{array}$ \\
\hline III & 512.06 & Dependable year & $456 \cdot 90$ & $85 \%$ & $\begin{array}{l}512 \mathrm{MW} \text { up to } 10-12- \\
71 \text { and } 414 \mathrm{MW} \text { from } \\
11-12-71 \text { to } 31-5-72\end{array}$ \\
\hline IV & $512 \cdot 06$ & Dry year & 445.92 & $81 \%$ & $\begin{array}{l}484 \mathrm{MW} \text { up to } 10-12- \\
71 \text { and } 432 \mathrm{MW} \text { from } \\
11-12-71 \text { to } 31-5-72\end{array}$ \\
\hline V & 512.06 & Dry year & $451 \cdot 41$ & $81 \%$ & $\begin{array}{l}484 \mathrm{MW} \text { up to } 10-12 \\
71 \text { and } 419 \mathrm{MW} \text { from } \\
11-12-71 \text { to } 31-5-72\end{array}$ \\
\hline VI & $512 \cdot 06$ & Dry year & $457 \cdot 20$ & $81 \%$ & $\begin{array}{l}484 \mathrm{MW} \text { up to } 10-12- \\
71 \text { ard } 402 \mathrm{MW} \text { from } \\
11-12-71 \text { to } 31-5-72\end{array}$ \\
\hline VII & 512.05 & $\begin{array}{l}\text { Dependable year } \\
\text { with month of May } \\
\text { as per driest year }\end{array}$ & $446 \cdot 23$ & $75 \%$ & $\begin{array}{l}512 \mathrm{MW} \text { or more up } \\
\text { to } 10-12-71 \text { and } \\
425 \mathrm{MW} \text { from } 11-12- \\
71 \text { to } 31-5-72\end{array}$ \\
\hline VIII & 512.06 & Dependable year & $452 \cdot 32$ & $85 \%$ & $\begin{array}{l}500 \mathrm{MW} \text { up to } 31-12 \text { - } \\
71 \text { and } 430 \mathrm{MW} \text { for } \\
1 / 72,3 / 72 \text { and } 5 / 72 \\
\text { and } 420 \mathrm{MW} \text { for } 2 / 72 \\
\text { and } 4 / 72\end{array}$ \\
\hline IX & $512 \cdot 76$ & Dependable year & $452 \cdot 32$ & $85 \%$ & $\begin{array}{l}500 \mathrm{MW} \text { upto } 31-12- \\
71 \text { and } 430 \mathrm{MW} \text { for } \\
1 / 72,3 / 72 \text { and } 5 / 72 \\
\text { and } 420 \mathrm{MW} \text { for } 2 / 72 \\
\text { and } 4 / 72 \text {. }\end{array}$ \\
\hline $\mathbf{X}$ & $512 \cdot 76$ & -do- & 445.62 & $85 \%$ & -do- \\
\hline XI & $512 \cdot 76$ & Actual & 445.62 & $85 \%$ & -do- \\
\hline
\end{tabular}

Note:

(1) Study Nos. I to VIII are BMB Water Power Studies for 1971-72 (Mehndiratta \& Hoon 1973).

(2) Study No. XI is one of actual operation.

5.4f Stored volume: For planning studies, live storage available above dead storage level (DSL) is used in the different studies. In case carryover was planned for, carryover storage was estimated from volume elevation curves and deducted from live storage above DSL to give utilizable storage with carryover. It is presumed that the losses due to evaporation and infiltration from the reservoir are considered by $\mathrm{BM}$ in the specification of demands or in specifying inflows. The total volume of water for 
utilization during the years is assumed to be the sum of dependable year inflows and the utilizable storage from the reservoir as in the water power studies of BMB. For studies of actual operation the volume of water actually utilized during the depletion period is used. The details of the data are given in table 10 .

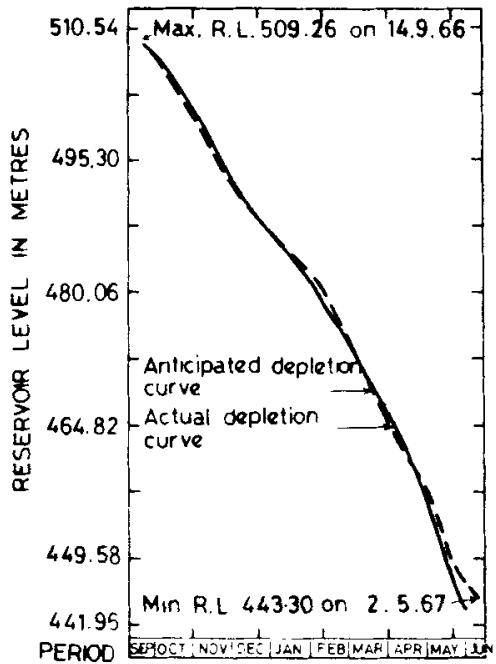

2. $1966-67$
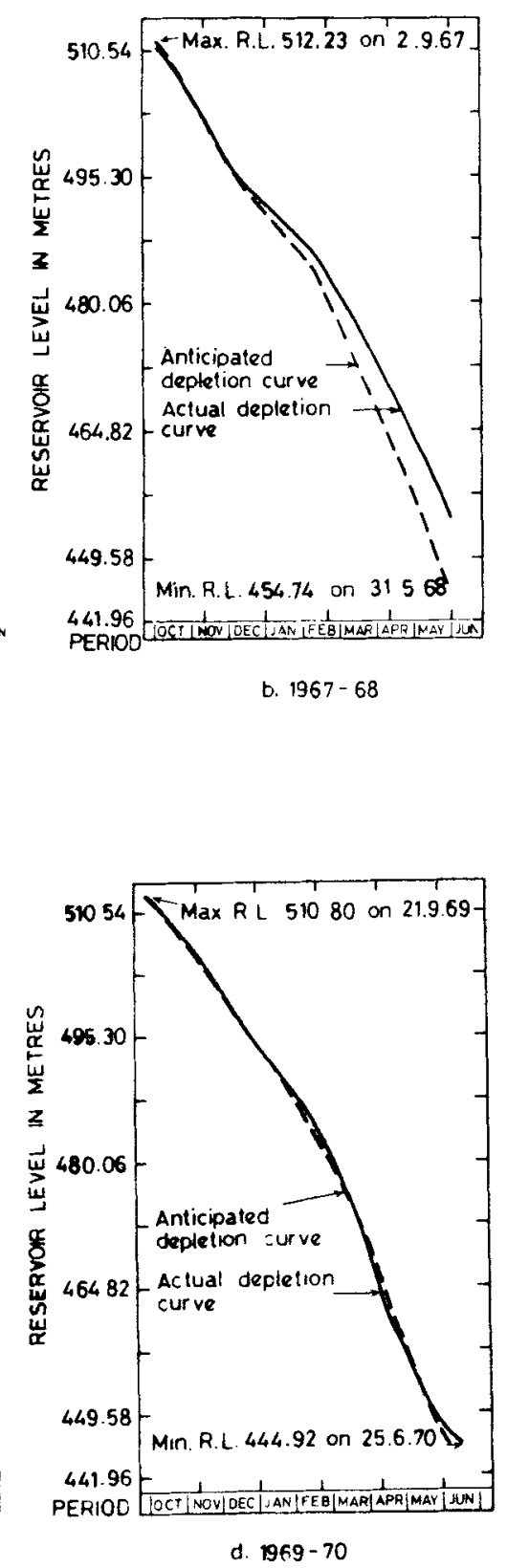

d. $1969-70$

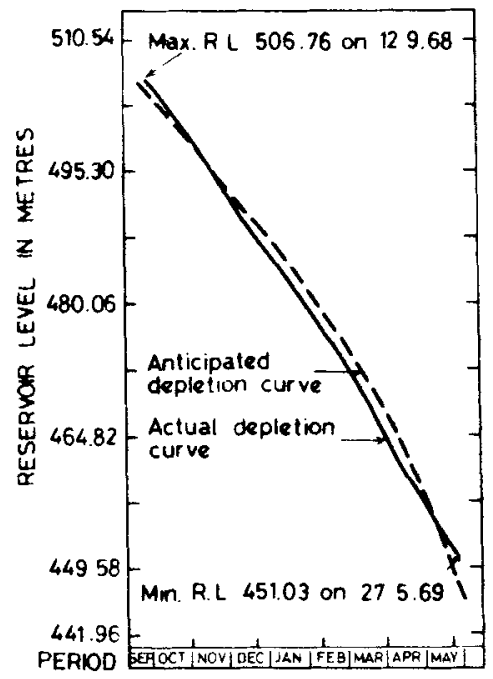

c. $1968-69$ 


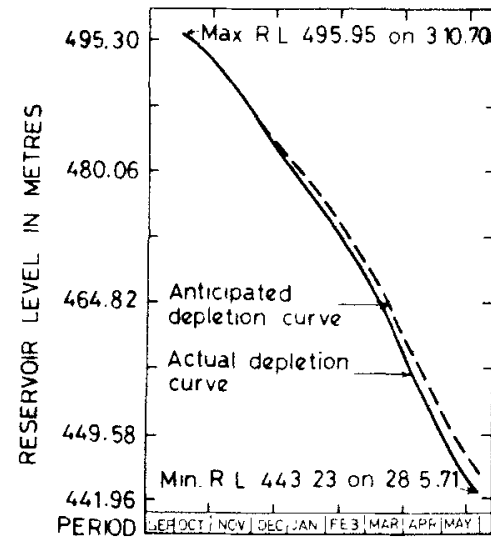

e. $1970-71$

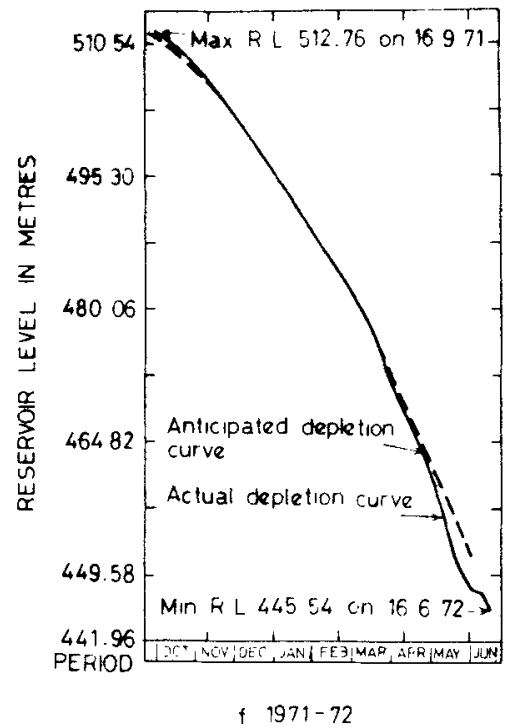

Figere 3. a, b; c, d; e, f; Anticipated and actual depletion curves. (Mehndiratta \& Hoon 1973)

\subsection{Derivation of irrigation and power transformation curves}

The maximum level of firm power that can be developed for a given $\mathrm{RF}$ is determined by solving the LP problem. The values of RF used are $0.6,0.65,0.7,0.75,0.8,0.85,0.9,0.95$ and 1.0 . The results of the studies of the planned and actual utilization of the reservoir storage from 1966 to 1972 are given in table 11 and the corresponding transformation curves are plotted in figure 4.

Carryover storage was an additional variable besides irrigation and power in 1971-72. The details and results of the studies with various carryover storages considered in the planning studies in 1971-72 are given in tables 12 and 13. The graphical representation of the concept of transformation surfaces and the resulting transformation surface for Bhakra are plotted in figures 5 and 6 . The transformation curves, between irrigation (RF) and carryover storage, and between firm power and carryover storage, are given in figures 7 and 8 and explained later in $\$ 5.7 \mathrm{~b}$.

\subsection{Analysis of transformation curves}

The transformation curves for the planned and actual operation of the reservoir for six years are generally similar in shape. The curves for 1966-67 are a little different in shape at higher RF levels and this is presumably due to very low Ravi-Beas contributions in the depletion period of that year (table 6b).

The difference between the curves for planning and operation in each year is due to the difference in the assumed depletion period inflows and actual inflows. The actual inflow is much smaller than the assumed inflow in the dry year 1970-71; slightly smaller 

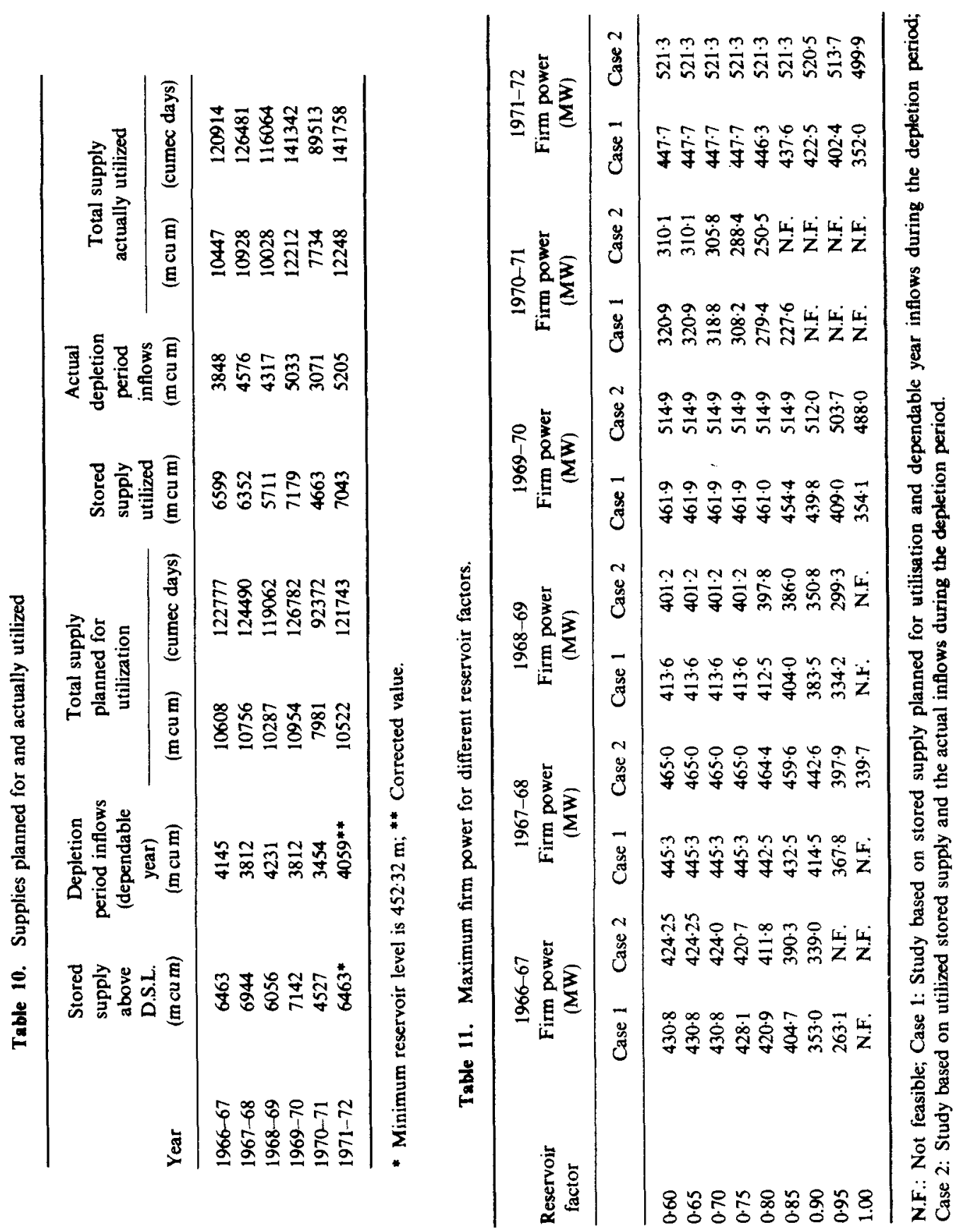
Study of Bhakra reservoir operation

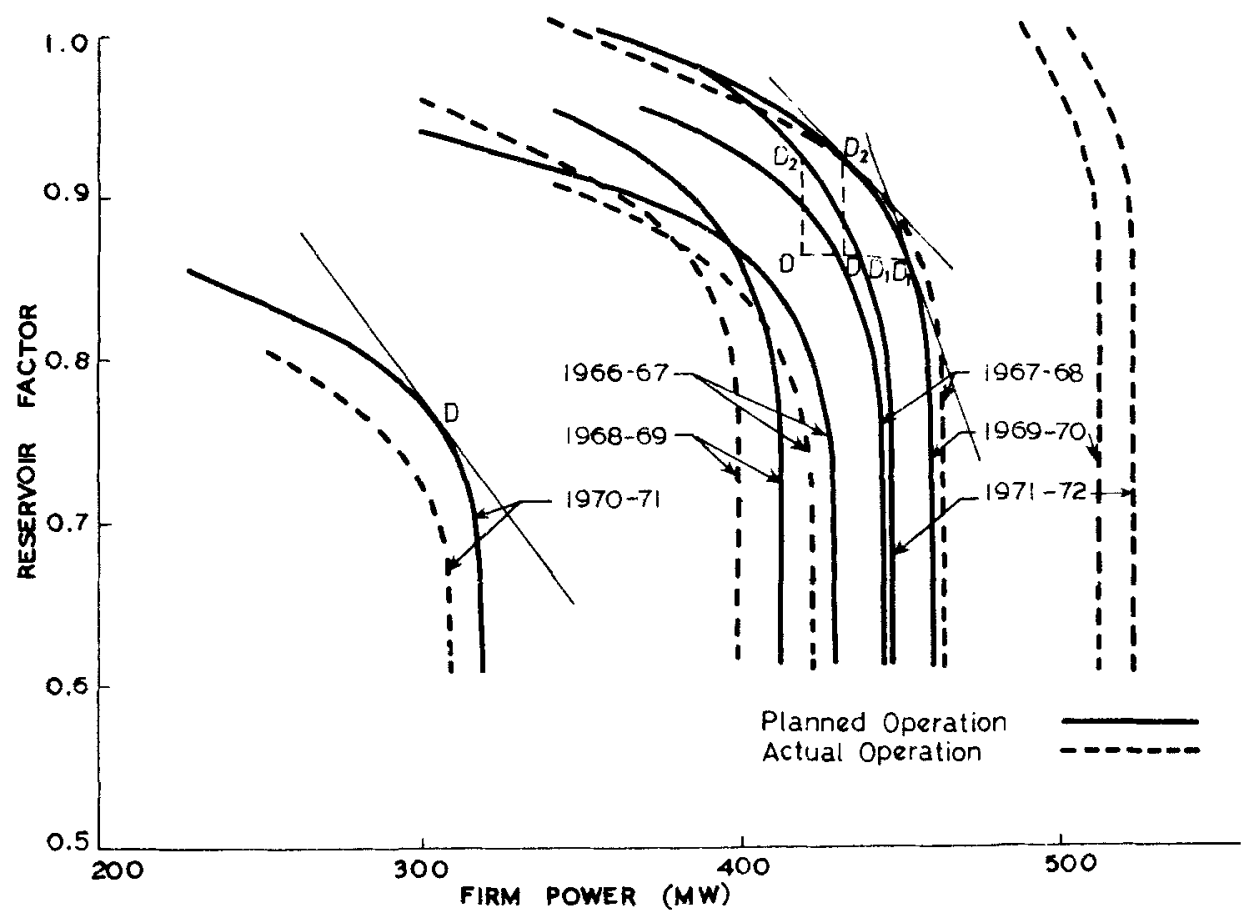

Figure 4. Transformation curves for the Bhakra reservoir (1966-72)

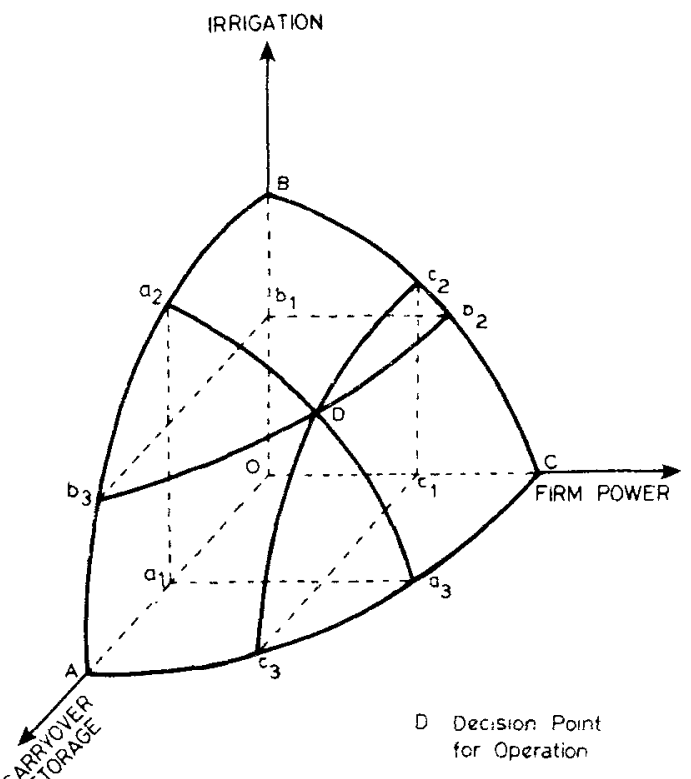

Figure 5. Graphical representation of transformation surface. 


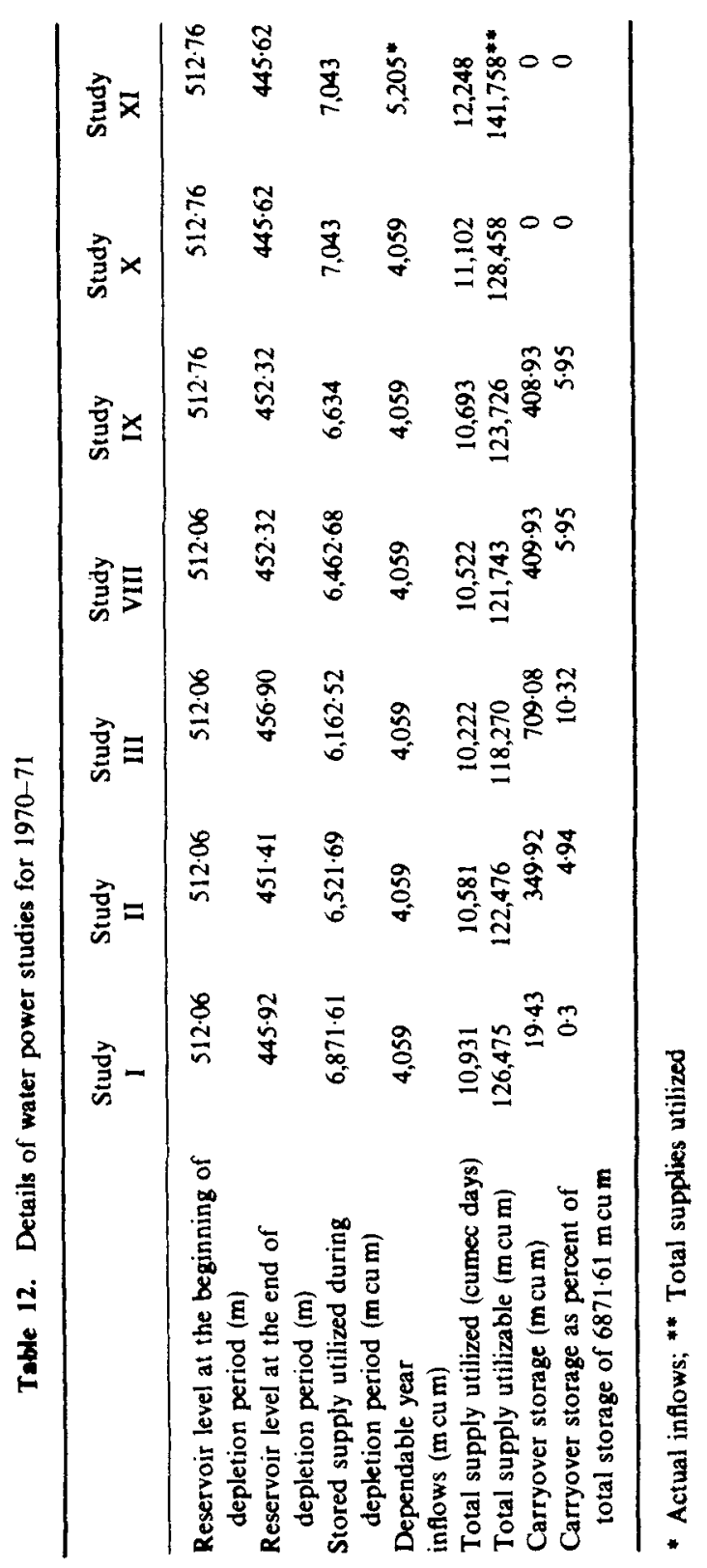


Table 13. Maximum firm power for different reservoir factors and carryover storages (water power studies for 1971-72)

\begin{tabular}{|c|c|c|c|c|c|c|c|}
\hline \multirow{2}{*}{$\begin{array}{l}\text { Reservoir } \\
\text { factor }\end{array}$} & \multicolumn{7}{|c|}{ Firm power (MW) } \\
\hline & Study 1 & Study 2 & Study 3 & Study 8 & Study 9 & Study 10 & Study $11^{*}$ \\
\hline 0.60 & $465 \cdot 1$ & 4502 & $434 \cdot 9$ & $447 \cdot 7$ & 455.0 & 472.4 & $521 \cdot 3$ \\
\hline 0.65 & $465 \cdot 1$ & $450 \cdot 2$ & 434.9 & $447 \cdot 7$ & 455.0 & 472.4 & $521 \cdot 3$ \\
\hline 0.70 & $465 \cdot 1$ & $450 \cdot 2$ & 434.9 & $447 \cdot 7$ & $455 \cdot 0$ & 472.4 & $521 \cdot 3$ \\
\hline 0.75 & $465 \cdot 1$ & $450 \cdot 2$ & $434 \cdot 6$ & $447 \cdot 7$ & 455.0 & 472.4 & $521 \cdot 3$ \\
\hline 0.80 & $464 \cdot 7$ & $449 \cdot 1$ & 431.9 & $446 \cdot 3$ & $454 \cdot 2$ & $472 \cdot 3$ & $521 \cdot 3$ \\
\hline 0.85 & $461 \cdot 3$ & $441 \cdot 2$ & $419 \cdot 3$ & 437.6 & 447.9 & 469.8 & $521 \cdot 3$ \\
\hline $0-90$ & $448 \cdot 2$ & $426 \cdot 3$ & $403-2$ & 422.5 & 433.5 & $458 \cdot 6$ & 520.5 \\
\hline 0.95 & $432 \cdot 2$ & 407.7 & $369 \cdot 2$ & 402.4 & 416.4 & $443 \cdot 2$ & 513.7 \\
\hline 1.00 & $400-9$ & 359.0 & $314 \cdot 1$ & 352.0 & 372.5 & $420 \cdot 5$ & $500 \cdot 0$ \\
\hline $\begin{array}{l}\text { Carryover } \\
\text { storage } \\
\text { (m cu m) }\end{array}$ & $19 \cdot 4$ & $349 \cdot 9$ & $709 \cdot 1$ & $408 \cdot 9$ & $408 \cdot 9$ & 0 & 0 \\
\hline
\end{tabular}

* Actual operation

in the below average years 1966-67 and 1968-69; slightly larger in the above average year 1967-68 and very much larger in the wet years $1969-70$ and 1971-72. It shows that using dependable year inflows for planning every year irrespective of how wet the year has been and how high the reservoir has filled up led to very conservative planning in wet years and the opposite of it in a dry year. It is not sound practice. It seems possible to delineate an average year with a transformation curve between the above average and

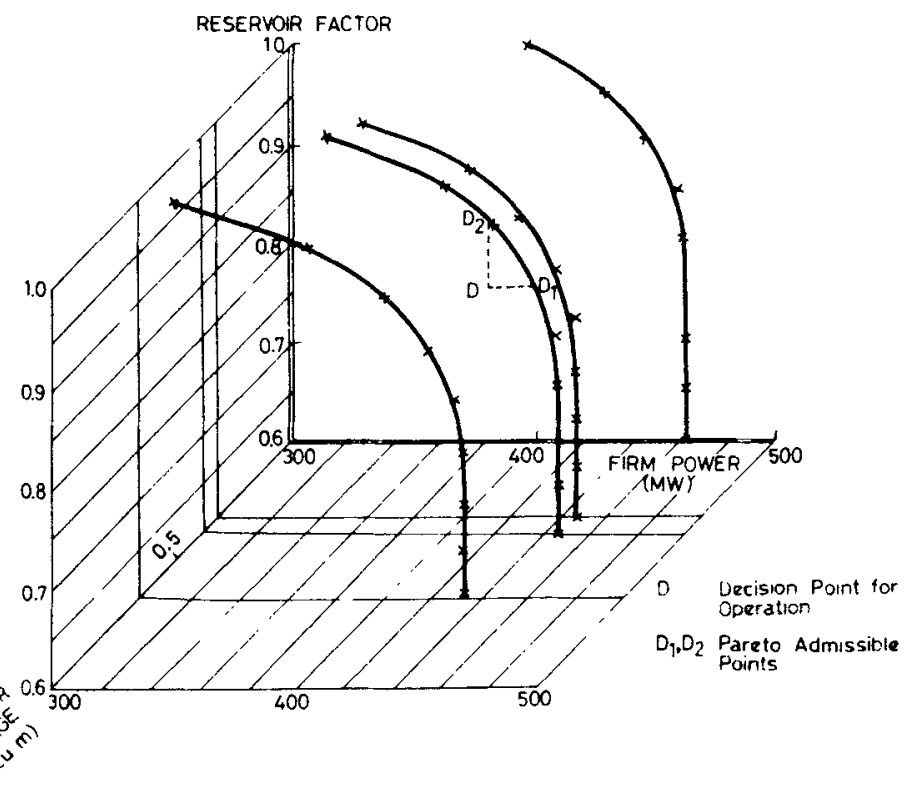

Figure 6. Transformation surface for the Bhakra reservoir. 


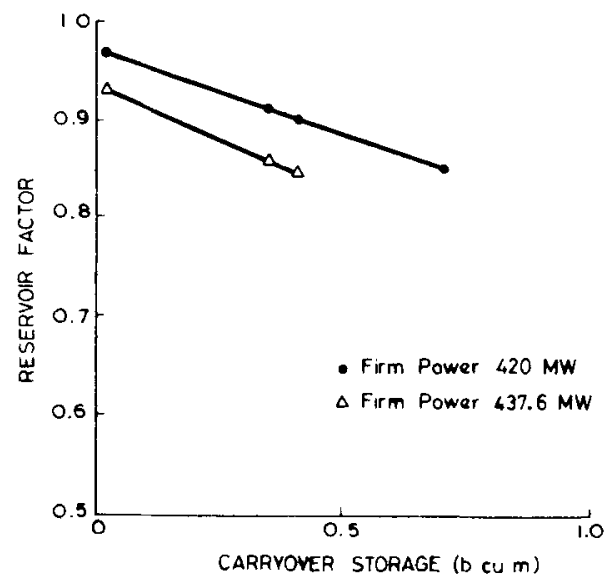

Figure 7. Transformation curve at constant firm power (1971-72).

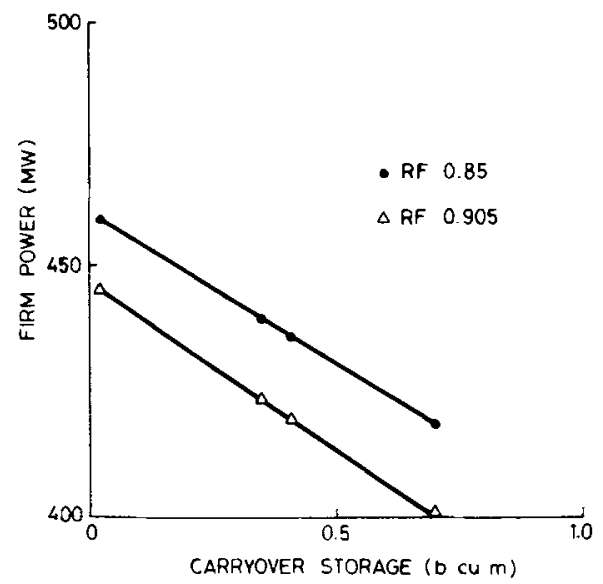

Figure 8. Transformation curve at constant reservoir factor (1971-72).

below average years for which the assumption of dependable year inflows in depletion period would be correct. Forecasting models for the stochastic inflows (Krishnasami 1976) are required to predict depletion period inflows for use in planning.

The points of operation $D$ chosen in the planning studies in 1969-70 and 1971-72 (figure 4) lie inside the respective transformation curves indicating that the planned operation is inferior and nonoptimal. The point $D$ could be moved on to the curve at $D_{1}$ or $D_{2}$ and the operation would be Pareto-superior to that at $D$. A higher firm power level would be attained for the same RF of 0.85 at $D_{1}$ while a higher RF would be obtained for the same firm power level at $D_{2}$. RF planned was never higher than 0.85 and so it seems reasonable to suppose that the points $D_{1}$ would be the decision points of вмв for operation in 1969-70 and 1971-72.

The RF planned for was 0.75 in the dry year 1970-71. The decision point chosen in planning is not feasible with respect to the actual transformation curve. The firm power 
level planned for was stuck to and the adverse impact of the shortage must have been borne by irrigation only. So the actual RF provided would have been lower than 0.75 .

Irrigation supplies at RF of 1 were feasible in 3 out of 6 years and at RF of 0.9 to 0.95 in 2 out of 6 years. In the dry year an RF of only 0.8 was feasible.

Firm power levels planned for varied from $312 \mathrm{Mw}$ in a dry year to $438 \mathrm{mw}$ in a wet year. In actual operation it seemed that 510 to $520 \mathrm{MW}$ of power was generated in the wet years of 1969-70 and 1971-72 and 280 to $300 \mathrm{Mw}$ in the dry year of 1970-71. The high order of fluctuations in firm power from year to year can be reduced by carryover storage from wet to dry years. For example, a carryover of about $1500 \mathrm{~m} \mathrm{cu} \mathrm{m}$ storage from 1969-70 to 1970-71 would have facilitated operation in both years around the level of an average year (1968-69) with firm power of about 400 to $420 \mathrm{MW}$. The recommendation of Minhas et al (1972) that a high dead storage level should be maintained for high levels of firm power (which are possible in years of good inflows) implies, in a way, the concept of carryover storage. Carryover storage was planned for in 1971-72 possibly because of the experience of the previous two years, but in actual operation this sound policy was not carried out.

Irrigation and power are almost wholly complementary up to an RF level of about 0.9 in years of good inflows but the complementarity could not be exploited because of the uncertainty of depletion period inflows. This again points to using appropriate streamflow forecasting models for planning reservoir operation.

\section{7 "Top-down" and "bottom-up" planning}

The transformation curves provide the frontier on which an optimal decision point for operation should lie. If the social welfare function or the preference function of the decision makers is available, the optimal point is obtained as the point of tangency between the transformation curve and the welfare function or preference curve respectively and the slope of the tangent gives the trade-off between the objectives. The slope of the tangent to the transformation curve gives the marginal rate of technical transformation between the objectives at that level of attainment of the objectives. The slope of the tangent to the preference curve provides a measure of the relative marginal economic worth of the two objectives (ratio of the shadow prices) at that level of attainment of the objectives. At the decision point they are equal and the converse is also true.

Well-defined preference functions do not exist. Shadow prices of the objectives vary from time to time and depend on the levels of attainment of the objectives. They need to be derived from an overall economic framework by a central planning organisation and given to the project operators for use in decision-making. This is "top-down" planning. If the ratio of shadow prices of the objectives are so defined exogenously (along the transformation curve) the point on the transformation curve where the slope equals this ratio defines the decision point. If it is not available from decision makers it is possible to arrive at a decision point by interaction with the decision makers using techniques like swT method or Paretian analysis. In the absence of these, a "bottom-up" planning procedure seems possible.

5.7a Analysis and discussion of implied trade-offs: The results presented in $\S 5.4$ are analysed and discussed in the framework of "bottom-up" methodology to elicit the trade-offs implied in the choice of the decision points in the planned and actual operation of the reservoir during six years. 
The trade-offs between irrigation and firm power in the planned and actual operation for the six years are given in table 14. The trade-offs implied in planned operation vary from $200 \mathrm{MW} / \mathrm{RF}$ in average years to $360 \mathrm{MW} / \mathrm{RF}$ in a dry year. Since the results indicate a higher trade-off for irrigation in a dry year, the value system adopted in planning is consistent.

In 1969-70 (figure 4), the trade-offs of $200 \mathrm{MW} / \mathrm{RF}$ at $D_{1}$ and $500 \mathrm{MW} / \mathrm{RF}$ at $D_{2}$ provide the bounds for the marginal rates of transformation implied in the choice of decision point $D$ for operation. The BMB has used a maximum RF of 0.85 for operation (tables 7,8 and 9). Assuming, therefore, an RF of 0.85 corresponding to $D_{1}$ the trade-off implied is $200 \mathrm{MW} / \mathbf{R F}$. The trade-off on the transformation curve of actual operation at the level of $D_{1}$ corresponding to RF of 0.85 is $0.0 \mathrm{MW} / \mathrm{RF}$. This implies that, in actual operation, there is complete complementarity between irrigation and firm power up to $\mathrm{RF}$ of 0.85 and that the irrigation supply could have been increased upto RF levels of 0.9 or even upto 1 with a small loss of firm power. Even at an RF of 1.0,50 MW more of firm power than that planned for would have been produced (table 11).

In the dry year 1970-71 (figure 4) the trade-off between irrigation and power implied by the decision is $360 \mathrm{MW} / \mathrm{RF}$. The planned operation at point $D$ is not feasible for actual inflows. If an RF level of 0.75 was maintained, a firm power level of $288.4 \mathrm{MW}$ would have been reached on the transformation curve for actual operation and it would have meant a trade-off of $490 \mathrm{MW} / \mathrm{RF}$ at that point. This is larger than the trade-off in an average year. During the early part of the depletion period from 3 October 1970 to about 15 December 1970 the operation was as per the plan, i.e. at point $D$ with RF of 0.75 and firm power level of $400 \mathrm{MW}$ (figure 3e). The adverse effect of the shortage seems to have been borne by the latter part of the depletion period from 15 December 1970 to 31 May 1971. The average power generation for the year 1970-71 was $335 \mathrm{MW}$. It can be deduced from these that the RF level achieved was certainly less than 0.75 and must have been somewhere between 0.65 and 0.7 with a trade-off of $160 \mathrm{MW} / \mathrm{RF}$ or less. This, in turn, implies a higher value for power than irrigation compared to an average year. This indicates not only a contradiction between planning and operation but also an inconsistency in economic evaluation. If, as pointed out earlier, the reservoir was not depleted as it was in 1969-70 but some storage was carried over to 1970-71, it would have greatly cushioned the adverse impact due to poor inflows in 1970-71 and enabled the achievement of a higher $\mathrm{RF}$ for irrigation.

Table 14. Trade-off between firm power and irrigation

\begin{tabular}{lccc}
\hline Irrigation & \multicolumn{2}{c}{ Trade-off $(\mathrm{MW} / \mathbf{R F})$} \\
Year & $\begin{array}{c}\text { (RF) } \\
\text { (RF) }\end{array}$ & $\begin{array}{c}\text { Planned } \\
\text { operation }\end{array}$ & $\begin{array}{c}\text { Actual } \\
\text { operation }\end{array}$ \\
\hline $1966-67^{*}$ & 0.85 & 450 & 600 \\
$1867-68$ & 0.85 & 260 & 210 \\
$1968-69$ & 0.85 & 240 & 360 \\
$1969-70$ & 0.85 & 200 & 0 \\
$1970-71$ & 0.75 & 360 & 490 \\
$1971-72$ & 0.85 & 230 & 0 \\
\hline
\end{tabular}

* Ravi-Beas contribution is low as compared to other years. 
5.7b Transformation surface for 1971-72: The concept of the transformation surface amons the three objectives has been illustrated in figure 5. $A B C$ constitutes the surface bounded by the three coordinate planes. $D$ is the decision point for operation. If it is on the surface, it is Pareto-optimal. Curves $a_{2} a_{3}, b_{2} b_{3}$ and $c_{2} c_{3}$ pass through the decision point and lie respectively in planes $a_{1} a_{2} a_{3}$ parallel to the coordinate plane $B O C, b_{1} b_{2} b_{3}$ parallel to $O A C$ and $c_{1} c_{2} c_{3}$ parallel to $O A B$. The trade-off implied by decision point $D$ between any two of the objectives can be derived as the negative of the slope of the curve in the plane parallel to the coordinate plane defined by the same objectives.

For 1971-72, water power studies for planning the reservoir operation were conducted by вмв assuming different levels of irrigation and firm power supplies and different carryover storages. They are listed in table 9. Four of the studies, viz., I, II, III and VIII assumed an irrigation level at RF 0.85 and dependable year inflows during depletion period but they differ in that they assume different carryover storages. Details of these studies are given in table 12 .

The maximum firm power levels for different reservoir factors and carryover storages are given in table 13. The transformation surface among the three objectives, irrigation, firm power and carryover storage for the four planning studies is shown in figure 6 . The BMB decided to operate the reservoir according to study No. VIII with a carryover storage of $408.93 \mathrm{~m}$ cu m, a firm power level of $420 \mathrm{MW}$ and RF of 0.85 . A firm power level of $437.6 \mathrm{MW}$ was possible for an RF of 0.85 and carryover storage of $408.93 \mathrm{~m}$ cu m (table 13, figure 4). Hence the decision point $D$ (figure 4) is inside the transformation curve and though feasible is not Pareto-optimal. For the same carryover storage, any operation between $D_{1}$ (RF of 0.85 and firm power of $437.6 \mathrm{MW}$ ) and $D_{2}$ (RF of 0.905 and firm power of $420 \mathrm{MW}$ ) will be better than the point $D$ chosen and will be Paretosuperior. The trade-offs implied by choice of $D_{1}$ or $D_{2}$ as decision points can be obtained from the transformation curves in figures 4,7 and 8 and are respectively 230 to $350 \mathrm{MW} / \mathrm{RF}$ between irrigation and power, 4824 to $5976 \mathrm{~m} \mathrm{cu} \mathrm{m/RF}$ between carryover storage and irrigation, and 60.6 to $67.6 \mathrm{MW} / \mathrm{b}$ cu m (billion cubic metres) between firm power and carryover storage. As the RF level of 0.85 was always adhered to as an upper limit, it appears that $D_{1}$ would have been the choice. Hence the trade-offs implied by $D_{1}$ are relevant indicators of decision makers' values.

The planning studies of BMB (table 9) assumed that the reservoir would reach an elevation of $512.06 \mathrm{~m}$ on 16 September 1971 . But the reservoir actually filled to an elevation of $512.76 \mathrm{~m}$ on that date with $171 \mathrm{mcum}$ more storage than planned for in these studies. Study Nos. IX and X (table 9) are revisions to account for this increase. Study No. IX assumes carryover storage of $408.9 \mathrm{mcum}$ as in study No. VI and corresponds to planned operation. Study No. $X$ assumes no carryover storage as in Study No. XI and corresponds to actual operation. They are reported in tables 12 and 13. The transformation curve for actual operation (figure 4) indicates that irrigation could have been supplied at an RF of 0.9 instead of 0.85 without any loss of firm power and this too at a power level of $521.30 \mathrm{mw}$ as against $420 \mathrm{mw}$ planned for. An increase in RF to 1 would have resulted in a loss of only about $20 \mathrm{Mw}$.

If the reservoir was operated according to the decision on 16 September, 1971 the carryover storage would have been much more than what was planned for because the excess of actual inflows over the assumed dependable year inflows, would have been stored, and carried over to the subsequent year. The reservoir elevation at the end of the depletion period would have been about $8 \mathrm{~m}$ higher than the planned elevation of $452.32 \mathrm{~m}$. In actual operation the reservoir was drawn down to about the dead storage 
elevation of $445.62 \mathrm{~m}$. Thus $1746 \mathrm{~m}$ cu m of water consisting of excess storage and excess inflows was used over and above the planned volume of $10,522 \mathrm{~m}$ cu $\mathrm{m}$ and all the excess was used in the interest of power alone and the trade-off implied is $0.0 \mathrm{MW} / \mathrm{RF}$ which considered irrigation above RF of 0.85 to be completely worthless. Such a value judgement needs justification. Thus, carryover storage, though planned for, was not realized in practice. This was particularly striking after the dismal experience of the previous year.

\section{Summary of results}

The analysis of the results of the study of the Bhakra reservoir operation from 1966 to 1972 indicates that (i) the depletion period inflows are correlated to the filling period inflows and planning should be based on appropriate estimates of depletion period inflows; (ii) an RF of 0.85 or above can be attained in an average year and an RF of 1 can be obtained at a loss of firm power of about $80 \mathrm{Mw}$ in an average year; (iii) planning and operation should be based on consistent estimates of economic parameters; and (iv) carryover storage will serve to reduce year to year fluctuations in firm power and irrigation levels.

\section{References}

Ansari N 1968 Economics of irrigation rates-a study in Punjab and Uttar Pradesh (Bombay: Asia Publishing House)

Irrigation Commission, Reports of the Irrigation Commission 1972 Vols. I, II, III. Ministry of Irrigation and Power, New Delhi

Krishnasami M 1976 Decoupled multivariate time series models for multisite streamflows Ph.D. thesis, IIT, Kanpur

Lamba S S, Prem K S 1975 Integrated development of rivers Sutlej, Beas, and Ravi for optimum utility of water in north-western areas of India, Presented at the IWRA Second World Congress on Water Resources, New Delhi, Reprint Vol. 3, p. 79

Mehndiratta K R, Hoon R N 1973 J. Central Board of Irrigation and Power India 30: 349

Minhas B S, Parikh K S, Srinivasan T N 1972 Sankhya, Indian J. Stat. B34: 105

Raj K N 1960 Some economic aspects of the Bhakra Nangal Project-a preliminary analysis in terms of selected investment criteria

Reidinger R B 1974 Econ. Dev. Cult. Change 23: 79

Singh H 1964 J. Central Board of Irrigation and Power, India 21: 471

Singh $\mathrm{J} 1965$ in Proceedings of the sixth regional conference on water resources development in Asia and the far East, Water Resources Series, United Nations, p. 281-295

Thomas H A Jr, Revelle R 1966 Manage. Sci. 12: 13-296 